\title{
CLINICAL TRIAL OF PARA-AMINO-SALICYLIC ACID IN THE TREATMENT OF RHEUMATOID ARTHRITIS
}

\author{
BY \\ J. J. R. DUTHIE and J. NORRIE SWANSON \\ From the Department of Medicine, University of Edinburgh, and the Unit for the \\ Treatment of Chronic Rheumatic Diseases, Northern General Hospital, Edinburgh
}

Para-amino-salicylic acid (PAS) has been used in recent years in the treatment of pulmonary tuberculosis. A review of some of the relevant literature has recently been given by Joules and Nassau (1949). Its action is believed to depend upon its close physico-chemical relationship to other substances taking part in the respiratory processes of the tubercle bacillus (Bernheim, 1940). Its pharmacology has been extensively studied by Way and others (1948).

Although the authors do not believe that the tubercle bacillus is concerned in the aetiology of rheumatoid arthritis, a number of workers have commented upon the common association of the two diseases and have advanced the view that in at least a proportion of cases of rheumatoid arthritis this association may be of aetiological significance (Copeman, 1936).

\section{Material}

A supply of the drug sufficient for the treatment of six cases was made available by the manufacturers. As it is generally agreed that rest and simple physiotherapy will lead to marked improvement in the majority of cases of rheumatoid arthritis, five patients were selected who continued to exhibit signs of clinical activity in the form of swelling, pain, and limitation of movement in the affected joints after several weeks of such non-specific treatment. The basic regime in these cases consisted of controlled rest, postural and remedial exercises, the application of splints to the affected joints, and a good diet supplemented by extra protein and vitamin concentrates. It was felt that any marked improvement which began after the administration of PAS could be fairly attributed to the drug. In one case (Case 2) treatment was limited to simple rest in bed, and PAS was given from the start. Details of all six cases are given in Table I. In two patients (Cases 1 and 2) $x$-ray changes were minimal and the possibility of complete recovery still existed. In two others (Cases 3 and 4 ) the disease was more advanced and permanent damage had taken place, although a good functional recovery was still possible. In the last two cases (Cases 5 and 6 ) the patients were severely crippled and still in a very active phase of the disease. 
TABLE I

\section{CLINICAL MATERIAL}

\begin{tabular}{c|c|c|c|c|c|c}
\hline Case & Sex & Age & $\begin{array}{c}\text { Duration } \\
\text { of } \\
\text { disease } \\
\text { in years }\end{array}$ & $\begin{array}{c}\text { Joint } \\
\text { involvement }\end{array}$ & $\begin{array}{c}X \text {-ray } \\
\text { appearances }\end{array}$ & $\begin{array}{c}\text { Duration } \\
\text { of basic } \\
\text { regime in } \\
\text { weeks }\end{array}$ \\
\hline 1 & F. & 20 & 1 & $\begin{array}{l}\text { Hands, wrists, } \\
\text { knees, ankles, feet }\end{array}$ & Osteoporosis & 8 \\
\hline 2 & M. & 29 & 3 & $\begin{array}{l}\text { Left knee, right } \\
\text { ankle, hands and } \\
\text { wrists }\end{array}$ & Osteoporosis & 0 \\
\hline 3 & F. & 28 & 4 & $\begin{array}{l}\text { Hands, wrists, left } \\
\text { knee, right ankl }\end{array}$ & $\begin{array}{l}\text { Osteoporosis; } \\
\text { cartilage loss }\end{array}$ & 3 \\
\hline 5 & F. & 28 & $4 \frac{1}{2}$ & $\begin{array}{l}\text { Hands, wrists, } \\
\text { knees }\end{array}$ & $\begin{array}{l}\text { Osteoporosis; } \\
\text { cartilage loss; } \\
\text { ankylosis }\end{array}$ & 6 \\
\hline 6 & F. & 58 & 2 & $\begin{array}{l}\text { Hands, wrists, } \\
\text { right knee, left } \\
\text { ankle, feet }\end{array}$ & $\begin{array}{l}\text { Osteoporosis; } \\
\text { cartilage loss }\end{array}$ & 9 \\
\hline F. & 53 & 5 & $\begin{array}{l}\text { Hands, wrists, } \\
\text { elbows, shoulders, } \\
\text { knees, feet, right } \\
\text { temp-mandib. }\end{array}$ & $\begin{array}{l}\text { Osteoporosis; } \\
\text { cartilage loss }\end{array}$ & 12 \\
\hline
\end{tabular}

\section{Dosage and Technique}

PAS was given orally in five doses of $3 \mathrm{~g}$. at three-hourly intervals throughout the day, a total of $15 \mathrm{~g}$. in twenty-four hours. Various flavouring agents were used in an attempt to mask the unpleasant taste of the drug. None was found to be effective, and patients preferred to swallow each dose quickly and follow it with a large glass of water.

Estimations of the plasma concentration of the drug were made weekly or more often. It was found that the specimen of blood obtained immediately before administration of the next dose contained the minimum concentration, and that obtained one hour after, the maximum. The average minimum concentration and the highest maximum for each

TABLE II

\section{PLASMA CONCENTRATION}

\begin{tabular}{c|c|c}
\hline Case & $\begin{array}{c}\text { Average minimum } \\
\text { concentration } \\
\text { mg. per cent. }\end{array}$ & $\begin{array}{c}\text { Highest maximum } \\
\text { concentration } \\
\text { mg. per cent. }\end{array}$ \\
\hline 1 & $7 \cdot 3$ & 27 \\
\hline 2 & $2 \cdot 5$ & 14 \\
\hline 3 & $7 \cdot 5$ & 15 \\
\hline 4 & $5 \cdot 0$ & Not recorded \\
\hline 5 & 5.0 & Not recorded \\
\hline
\end{tabular}
case are shown in Table II. The minimum figures compare favourably with those of Lehmann (1946), who found plasma levels of 2 to $7 \mathrm{mg}$. per cent. with doses of 10 to $15 \mathrm{~g}$. daily. The urinary output was measured weekly, and it was found that most of the drug was excreted rapidly by the kidneys. The biochemical techniques used for these estimations were those recommended by Dickenson and Kelly (1949).

A record was made weekly or more often of the blood 
sedimentation rate (B.S.R.), the haemoglobin percentage (Haldane method), the total and differential white cell count, and the prothrombin time. The technique employed to measure the B.S.R. was that of Westergren (1926), modified by using a dried mixture of ammonium and potassium oxalate as an anti-coagulant, the fall at the end of the first hour being recorded. Estimations of the prothrombin times were made by the method described by Quick (1935). Prothrombin indices were calculated by comparing the results with those obtained in controls.

TABLE III

DOSAGE AND RESULTS

\begin{tabular}{|c|c|c|c|c|c|c|c|c|}
\hline \multicolumn{3}{|c|}{ Case } & 1 & 2 & 3 & 4 & 5 & 6 \\
\hline \multirow{2}{*}{ PAS } & \multicolumn{2}{|c|}{$\begin{array}{l}\text { Duration } \\
\text { of course } \\
\text { (days) }\end{array}$} & 42 & 28 & 10 & 28 & 35 & 6 \\
\hline & \multicolumn{2}{|c|}{$\begin{array}{l}\text { Total dose } \\
\text { (g.) }\end{array}$} & 630 & 420 & 153 & 420 & 525 & 90 \\
\hline \multirow{2}{*}{$\begin{array}{l}\text { B.S.R. first } \\
\text { hour (mm.) }\end{array}$} & \multicolumn{2}{|c|}{ Initial } & 19 & 54 & 60 & 100 & 84 & 78 \\
\hline & \multicolumn{2}{|c|}{ Final } & 10 & 60 & 35 & 83 & 72 & 78 \\
\hline \multirow{2}{*}{ Weight (lb.) } & \multicolumn{2}{|c|}{ Initial } & 108 & 113 & 118 & 107 & 131 & - \\
\hline & \multicolumn{2}{|c|}{ Final } & 112 & 110 & 117 & 109 & 132 & - \\
\hline \multicolumn{3}{|c|}{ Toxic Manifestations } & $\begin{array}{l}\text { Mild ali- } \\
\text { mentary } \\
\text { symp- } \\
\text { toms }\end{array}$ & $\begin{array}{l}\text { Mild ali- } \\
\text { mentary } \\
\text { symp- } \\
\text { toms }\end{array}$ & $\begin{array}{l}\text { Moderate } \\
\text { alimentary } \\
\text { symp- } \\
\text { toms; } \\
\text { pyrexia; } \\
\text { cyanosis; } \\
\text { scarlatini- } \\
\text { form rash }\end{array}$ & $\begin{array}{l}\text { Mild ali- } \\
\text { mentary } \\
\text { symp- } \\
\text { toms; } \\
\text { slight } \\
\text { rash }\end{array}$ & $\begin{array}{l}\text { Mild ali- } \\
\text { mentary } \\
\text { symp- } \\
\text { toms; } \\
\text { tinnitus }\end{array}$ & $\begin{array}{l}\text { Severe } \\
\text { alimentary } \\
\text { symp- } \\
\text { toms; } \\
\text { pyrexia }\end{array}$ \\
\hline \multirow{3}{*}{\multicolumn{2}{|c|}{$\begin{array}{l}J \\
o \\
i \\
n \\
t \\
s\end{array}$}} & Pain & None & $\begin{array}{l}\text { Still } \\
\text { present }\end{array}$ & $\begin{array}{l}\text { Still } \\
\text { present }\end{array}$ & $\begin{array}{l}\text { Still } \\
\text { present }\end{array}$ & $\begin{array}{l}\text { Still } \\
\text { present }\end{array}$ & $\begin{array}{l}\text { Still } \\
\text { present }\end{array}$ \\
\hline & & $\overline{\text { Swelling }}$ & $\begin{array}{l}\text { Slight R. } \\
\text { knee only }\end{array}$ & Less & $\begin{array}{l}\begin{array}{l}\text { Still } \\
\text { present }\end{array} \\
\end{array}$ & Worse & $\begin{array}{l}\text { Slightly } \\
\text { less }\end{array}$ & $\begin{array}{l}\text { No } \\
\text { change }\end{array}$ \\
\hline & & $\begin{array}{r}\text { Func- } \\
\text { tion }\end{array}$ & Good & $\begin{array}{c}\text { Moder- } \\
\text { ately good }\end{array}$ & Poor & Poor & Poor & $\mathrm{Bad}$ \\
\hline \multirow[t]{2}{*}{$\begin{array}{l}\text { Final } \\
\text { Assessment }\end{array}$} & \multicolumn{2}{|c|}{$\begin{array}{l}\text { General } \\
\text { health }\end{array}$} & $\begin{array}{l}\text { Greatly } \\
\text { improved }\end{array}$ & $\begin{array}{l}\text { Slightly } \\
\text { improved }\end{array}$ & Worse & $\begin{array}{l}\text { Slightly } \\
\text { worse }\end{array}$ & Poor & Bad \\
\hline & \multicolumn{2}{|c|}{$\begin{array}{l}\text { Clinical } \\
\text { opinion }\end{array}$} & $\begin{array}{l}\text { Rate of } \\
\text { improve- } \\
\text { ment no } \\
\text { different } \\
\text { from that } \\
\text { while on } \\
\text { basic } \\
\text { regime } \\
\text { only }\end{array}$ & $\begin{array}{l}\text { Deterior- } \\
\text { ated on } \\
\text { PAS } \\
\text { alone; } \\
\text { improved } \\
\text { when } \\
\text { splints } \\
\text { and exer- } \\
\text { ciseadded }\end{array}$ & $\begin{array}{l}\text { Drug } \\
\text { stopped } \\
\text { because } \\
\text { of tox- } \\
\text { icity; no } \\
\text { progress }\end{array}$ & $\begin{array}{l}\text { Slight } \\
\text { deteri- } \\
\text { oration }\end{array}$ & $\begin{array}{l}\text { Drug } \\
\text { stopped } \\
\text { because } \\
\text { of tox- } \\
\text { icity }\end{array}$ & $\begin{array}{l}\text { Drug } \\
\text { stopped } \\
\text { because } \\
\text { of tox- } \\
\text { icity }\end{array}$ \\
\hline
\end{tabular}




\section{Toxicity}

The drug was not well tolerated by any of the patients, and all of them at one time or another complained of anorexia and nausea. Three patients continued with the drug without interruption until it was finally stopped. In one patient the drug had to be withdrawn after six days on account of severe vomiting, fever, and diarrhoea; in another because of a widespread scarlatiniform rash, fever, facial oedema, and cyanosis; and in a third because of persistent vomiting. This last patient was given a week's rest and the drug was resumed. It again produced severe nausea and vomiting.

In every case, with the exception of that in which the drug was only given for six days, a hypoprothrombinaemia developed. The prothrombin index was greatly reduced in two of them, the lowest figures being 57 per cent. in Case 1 and 50 per cent. in Case 3, the two cases which had the highest minimum plasma concentration of the drug. It was only moderately reduced in the remaining three. The three women of child-bearing age had normal periods, however, while the drug was being given.

\section{Results}

Table III gives the clinical details, duration of course, total dose, toxic effects, and final assessment in each case. No dramatic improvement was noted in any patient, either subjectively, objectively, or by laboratory examinations. In the one case (Case 2) in which splints and physiotherapy were withheld for the first three weeks while PAS was being given, the patient's condition deteriorated. When the drug was withdrawn and routine treatment started, he began to improve slowly and continued to do so thereafter.

There was no shift to the left of the Cooke-Arneth count as was recorded during the treatment of pulmonary tuberculosis (Erdei, 1948). All patients expressed the view that PAS was less effective in relieving pain than the simple analgesics which they had been in the habit of using.

\section{Summary}

(1) Para-amino-salicylic acid has been used in the treatment of six cases of rheumatoid arthritis.

(2) The drug does not appear to exercise any beneficial effect in this disease.

(3) Toxic symptoms were troublesome, and in three cases administration of the drug had to be stopped.

(4) Varying degrees of hypoprothrombinaemia were noted in all cases, indicating the need for caution when large doses are used over a long period in the treatment of tuberculosis.

The PAS was kindly supplied by Messrs. Ward Blenkinsop and Co., Ltd. The authors would like to acknowledge their debt to Miss E. B. Spreull of the Biochemistry Department and Miss M. B. Brown of the Haematological Laboratory of the Northern Group of Hospitals, Edinburgh, who were responsible for various biochemical and haematological estimations. 


\section{REFERENCES}

Bernheim, F. (1940). Science, 92, 204.

Copeman, W. S. C. (1936). Rep. Chronic Rheumat. Dis., 2, 24.

Dickenson, H. G., and Kelly, W. (1949). Lancet, 1, 349.

Erdei, A. (1948). Ibid., 1, 791.

Joules, F. E., and Nassau, E. (1949). Tubercle, 30, 98.

Lehmann, J. (1946). Lancet, 1, 15.

Quick, A. J. (1938). J. Amer. med. Ass., 110, 1658.

Way, E. L., Smith, P. K., Howie, D. L., Wesics, R., Swanson, R. (1948). J. Pharmacol. $93,368$.

Westergren, A. (1926). Amer. Rev. Tuberc., 14, 94.

\section{Essai Clinique de l'Acide Para-amino-salicylique dans le Traitement de l'Arthrite Rhumatismale}

RÉSUMÉ

(1) L'acide para-amino-salicylique fut employé dans le traitement de six cas d'arthrite rhumatismale.

(2) Il paraît que ce médicament n'a aucune action favorable dans cette maladie.

(3) Les symptômes toxiques furent très ennuyeux et dans trois cas son administration devait être interrompue.

(4) Dans tous les cas on a trouvé de l'hypo-prothrombinémie plus ou moins accentuée, ce qui conseille la prudence lorsqu'on en emploi de hautes doses pendant une période prolongée dans le traitement de la tuberculose.

\section{Ensayo Clínico del Ácido Para-amino-salicílico en el Tratamiento de la Artritis Reumatoide}

\section{RESUMEN}

(1) El ácido para-amino-salićlico fué empleado en el tratamiento de seis casos de artritis reumatoide.

(2) Este medicamento no parece ejercer acción favorable alguna en esta enfermedad.

(3) Los síntomas tóxicos fueron muy molestos y en tres casos hubo que interrumpir la administración del medicamento.

(4) En todos los casos se notó varios grados de hipo-protrombinemia indicando la necesidad de prudencia al administrar fuertes dosis durante un largo tiempo en el tratamiento de la tuberculosis. 